\title{
Castillo-palacio de La Calahorra, Granada: influencia de los factores climáticos y arquitectónicos en el deterioro diferencial de sus fábricas pétreas
}

\author{
Castle-palace of La Calahorra, Granada: influence \\ of climatic and architectural factors in differential deterioration \\ of their stone factories
}

\author{
J. J. Guardia(*), M. J. Varas(**), F. J. Suárez(*)
}

Recepción/Received: 11-IX-12

Aceptación/Accepted: $29-\mathrm{X}-12$

Publicado online/Online publishing: 9-I-13

\section{RESUMEN}

El castillo-palacio de La Calahorra es un edificio histórico (s. XVI) con una doble funcionalidad. El exterior es un castillo-fortaleza de estilo tardo-medieval, construido con mampuestos y sillarejos de una caliza cristalina de gran dureza y resistencia. El interior es un palacio renacentista, hecho con sillares de caliza micrítica y arenisca dolomítica, ambos materiales pétreos son porosos, blandos y poco resistentes. Todo el edificio tiene una tonalidad anaranjada debido a la pátina de hierro que tiñe sus fábricas y que es consecuencia de la acción del viento.

Existe un deterioro diferencial entre sus fábricas externas e internas, según el tipo de piedra empleado, la acción del agua de lluvia y el viento, y los defectos constructivos detectados. Mientras que la piedra exterior está en buen estado de conservación, las interiores sufren importantes procesos de deterioro, principalmente la caliza micrítica presente en las zonas ornamentales y decorativas del patio central.

Palabras-clave: fábricas pétreas; deterioro diferencial; agentes medioambientales; defectos constructivos.

\section{ABSTRACT}

The castle-palace of La Calahorra is a historical building (s. XVI) with a dual-function. The exterior is a castlefortress of late-medieval style, built with masonry and ashlar of a crystalline limestone of great hardness and strength. The interior is a Renaissance palace, made with ashlar limestone micritic and dolomitic sandstone, both stone materials are porous, soft and little resistant. The entire building has an orange hue due to the patina of iron that stained their factories and that is a consequence of the action of the wind.

There is a differential deterioration among its external and internal, depending on the type of stone used factories, the action of rain and wind and the construction defect detected. While the exterior stone is in good state of conservation, the interiors are important processes of deterioration, mainly the limestone micritic present in the ornamental and decorative areas of the central courtyard.

Keywords; stony Factories; differential deterioration; environmental agents; constructive faults.

(*) Universidad de Granada (Granada, España).

(**) Instituto de Geociencias (CSIC-UCM), (Madrid, España). 


\section{INTRODUCCIÓN}

El castillo-palacio objeto de este estudio se encuentra en la localidad de La Calahorra, a $73 \mathrm{Km}$ al Este de la ciudad de Granada y a $17 \mathrm{Km}$ al SE de la localidad de Guadix, por la carretera A-92. Se sitúa en el borde sur de la depresión de Guadix-Baza y a los pies de la ladera norte de Sierra Nevada (Figura 1).

Mandado construir entre 1509 y 1512 , en lo alto de un cerro (1.250 m de altura), por Don Rodrigo de Mendoza, dominaba visualmente todo el marquesado de Cenete y controlaba el paso hacia la Alpujarra y la costa mediterránea a través del Puerto de La Ragua. La obra fue ejecutada, primero por el arquitecto segoviano Lorenzo Vázquez, y por desavenencias con Don Rodrigo, pasó a encargarse de ella, el genovés Michale Carlone. Este arquitecto importó de Italia además de materiales de construcción, también técnicas y artistas (1-3).

Este edificio volvió a recobrar importancia durante la Rebelión de las Alpujarras o Guerra de los Moriscos (1568-1571). Posteriormente, fue abandonado durante siglos, hasta que a principios del siglo XX estuvo a punto de ser vendido y trasladado a Estado Unidos, antes de pasar a su actual propietario.

En 1922 fue declarado Bien de Interés Cultural (BIC) y Monumento Histórico-Artístico, y en 2010, se amplió esa protección a las zonas Oeste y Norte del cerro donde se asienta. Actualmente, es considerado como la primera obra de envergadura en la que se ha documentado el trabajo de artistas italianos en nuestro país (1).

El objetivo que se persigue con este trabajo es el de: a) identificar, ubicar y caracterizar los principales materiales de construcción empleados, priorizando las variedades pétreas utilizadas en su estructura y según los estilos arquitectónicos reconocidos en el edificio, b) valorar su estado de conservación y posibles factores y agentes de deterioro involucrados, y c) localizar las zonas de extracción originales o similares, para poder afrontar futuras intervenciones en la piedra natural del inmueble.

\section{INTRODUCTION}

The castle-palace studied in the present research lays in the town called La Calahorra, situated $73 \mathrm{~km}$ east from Granada and $17 \mathrm{~km}$ southeast from the town of Guadix, using the A-92 highway. It is placed in the south edge of the Guadix-Baza depression and at the feet of the north hillside of Sierra Nevada (Figure 1).

The castle-palace was constructed by Don Rodrigo de Mendoza between 1509 and 1512 situating the construction on the top of a hill (1250 m height). The whole marquisate of Cenete was visually dominated by the castle-palace and it controlled the passage towards the Alpujarra and the Mediterranean coast across the Ragua mountain pass. The work was carried out first by the Segovian architect Lorenzo Vázquez, but not coming to an agreement with Don Rodrigo it was the Genovese Michale Carlone who eventually took up the responsibility of doing the work. This architect himself imported some construction materials, techniques and even brought some artists from Italy (1-3).

The castle recovered its importance during the Alpujarras War, also known as the Moorish Rebellion (1568-1571). Later it was abandoned for centuries and at the beginning of the 20th century it was bought by its present-day owner. In the meanwhile, there was a time that it was almost sold and could have been moved to the United States stone-by-stone as it happened with Velez-Rubio palace which is at the Metropolitan Museum in New York.

In 1922 the castle was declared Heritage Site (BIC) and Historical-Artistic Monument. In 2010, this protection was extended to the west and north areas of the Castle-Palace hill. Nowadays, it is considered as the first significant building on which has documented the work of Italian artists in Spain (1).

The objectives of this work are: a) identify, localize and characterize the most essential construction materials used. It will be given priority to the stone varieties employed in its structure according to the architectural styles recognized in the building, b) To evaluate the conservation state and possible factors and agents involved in the deterioration of the castle-palace, and c) To locate original or similar extraction stone areas to be able to face up future works on the natural stone of the property. 


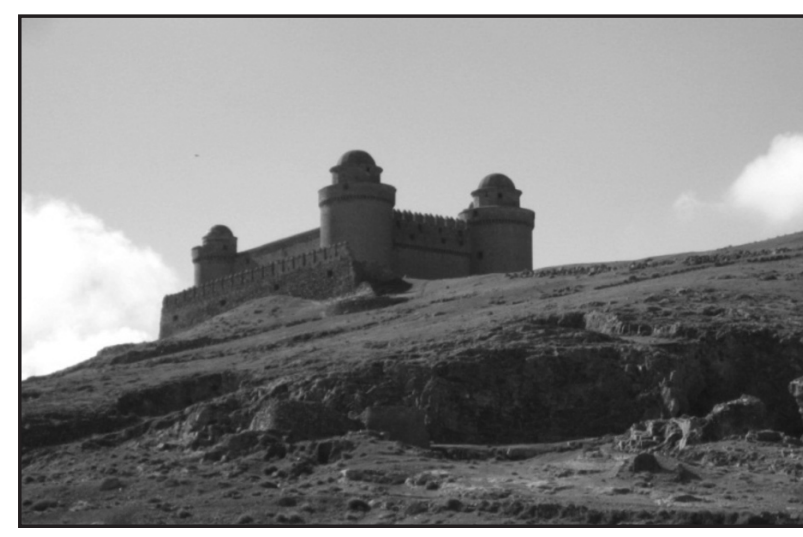

Figura 1. Castillo-palacio de La Calahorra sobre un cerro a los pies de Sierra Nevada, donde hay signos extractivos evidentes (bancales dispersos por todo el cerro que aprovechan el buzamiento de las capas rocosas).

Figure 1. La Calahorra Castle - palace on a hill at the feet of Sierra Nevada, where there are extractive evident signs (terraces scattered around the hill that take advantage of the dip of the rocky layers).

\section{ARQUITECTURA Y MATERIALES DE CONSTRUCCIÓN}

El castillo-palacio de La Calahorra fue construido aprovechando la cantería de una antigua fortaleza musulmana que había en ese cerro (2). El edificio tiene dos estilos constructivos claramente definidos y separados por el uso de diferentes materiales de construcción, en casa caso. El exterior del inmueble es un castillo-fortaleza de estilo tardo medieval, mientras que el interior encierra un palacio de estilo renacentista (Figuras 1 y 2 ).

Es un edificio de planta cuadrangular con cuatro torres circulares en sus esquinas. Tiene unas dimensiones aproximadas de $46 \times 32 \mathrm{~m}$, estando los lados mayores orientados en sentido Norte-Sur. En la fachada Oeste se adosa otro cuerpo rectangular de $26 \times 15 \mathrm{~m}$, dotado de un cubeto artillero y que rompe la armonía de la fortaleza, ya que alberga en su interior la gran escalera del palacio interior, una galería y un salón (Figura 3). Las dos torres del Sur son de menor diámetro que las del Norte $(10 \mathrm{~m}$ y $13 \mathrm{~m})$, y las cuatro tienen cúpulas semiesféricas (2). Fue una construcción novedosa, ya que se colocaron torres cilíndricas en las esquinas del edificio y no cúbicos como se llevaba en la época; confiriéndole, de esta forma, mayor resistencia al impacto de los proyectiles pues repartía los esfuerzos hacia los laterales, aumentando así la resistencia de su superficie (3).

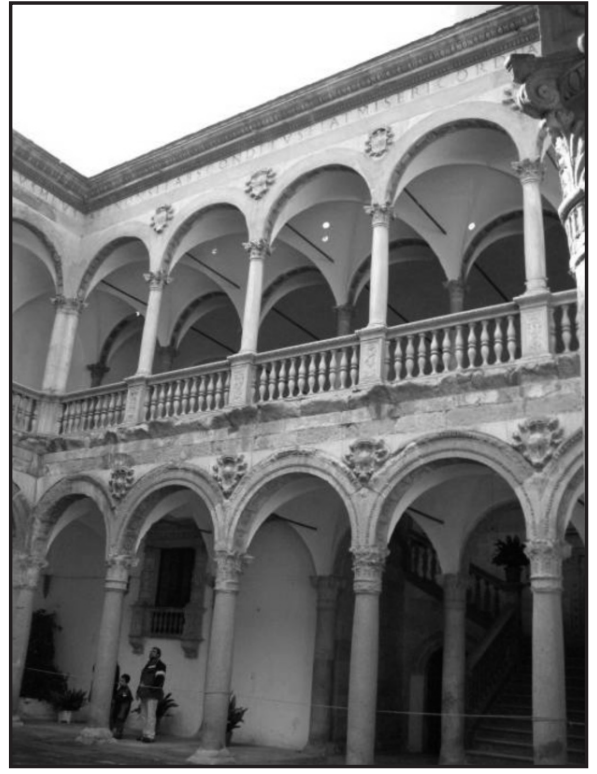

Figura 2. Fachada Oeste del patio central, con la escalera principal a la derecha. Los signos de deterioro en la decoración de las arcadas de la planta baja son muy visibles y afectan a la misma variedad pétrea.

Figure 2. Façade West of the central courtyard, with the principal stairs to the right. The decay signs in the decoration of the arcades of the ground floor are very visible and affect the same stone variety.

\section{ARCHITECTURE AND CONSTRUCTION MATERIALS}

La Calahorra castle - palace was built using the stonework from a Muslim fortress existing previously in the hill (2). The building has two styles of construction clearly defined and separated by different construction materials in each case. The outside part of the building is a later medieval castle - fortress, whereas the inside part encloses a renaissance palace (Figures 1 and 2).

The building has quadrangular floor with four circular towers in its corners. Its approximate dimensions are $46 x$ $32 \mathrm{~m}$. The bigger sides are north - south facing. The west façade leans against a rectangular body of $26 \times 15 \mathrm{~m}$, endowed with an artillery barrel (cubete artillero) which breaks the harmony of the fortress, as it contains the palace staircase, a gallery and a lounge (Figure 3). Both south towers have a minor diameter than the north ones $(10 \mathrm{~m}$ and $13 \mathrm{~m})$, and the four have semispherical cupolas (2). It was a novel construction, caused by the fact of using cylindrical towers in the corners of the building instead of the cubic ones as it was typical at the time. This provided a greater resistance to the impact of the missiles since it distributed the efforts towards the wings, increasing as a result the resistance of its surface (3). 


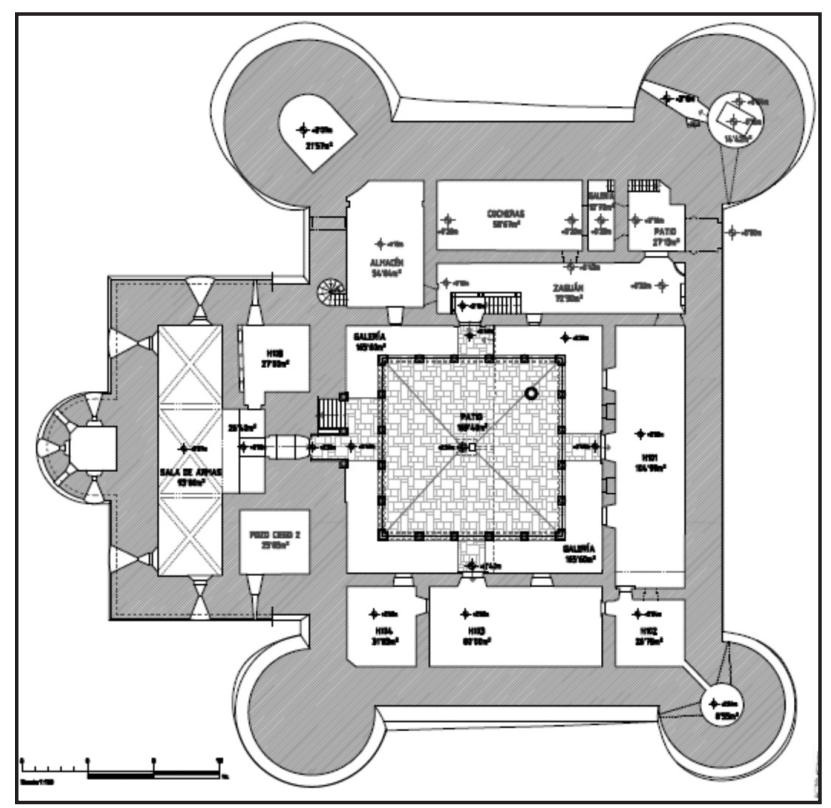

Figura 3. Plano 1:1000 de la planta baja del inmueble. Orientación Norte hacia arriba.

Figure 3. Plane 1:1000 of ground floor of the building. North orientation up.

La fábrica exterior es una mezcla de mampostería careada y sillarejos, rejuntados con mucho mortero de cal. La base de los muros y de las torres no es vertical, sino que presenta un talud defensivo con una inclinación aproximada de $60^{\circ}$ y que alcanza una altura que oscila de 1 a $2 \mathrm{~m}$, según el desnivel del terreno. En la construcción del castillo, sólo se ha empleado una variedad pétrea, una caliza gris oscura extraída del propio cerro donde se ubica. El muro Norte y parte del muro Sur, así como la torre NO y las dos torres pequeñas del Sur, se asientan sobre la zona que fue una de sus canteras, identificándose en su parte baja, los estratos pétreos buzando hacia el Norte (Figura 4). Los canteros aprovecharon las grietas, diaclasas y planos de estratificación que presenta esta formación geológica para extraer los mampuestos y sillarejos necesarios. Por ello, que el grueso y/o la soga de las piezas utilizadas en la zona externa del castillo, presentan dimensiones similares a los espesores de los estratos rocosos limítrofes (18 a $30 \mathrm{~cm}$; Figuras 1 y 5). Además, a simple vista, toda la fábrica pétrea externa (gris), junto con su rejuntado (blanco), tienen en superficie una pátina de tonalidad anaranjada que homogeneíza el color del conjunto (Figuras 4 y 5).

El palacio renacentista de dos plantas, está constituido por una serie de dependencias comunicadas entre sí y con un patio central de planta cuadrada ( $20 \times 20 \mathrm{~m}$ ) (Figura 2). El patio está rodeado por dos plantas de galerías superpuestas con cinco arcadas por cada lado. Las galerías cuentan con bóvedas de arista que descansan hacia el
The outside stone masonry is a mixture of lime rubbles and rough ashlars, grouted with a large amount of lime mortar. The base of the walls and of the towers is not vertical, but it presents a defensive slope with an approximate inclination of $60^{\circ}$ that reaches a height ranging from 1 to $2 \mathrm{~m}$, according to the difference of the area. In the construction of the castle, there has only been used a stone variety, a grey dark limestone extracted from the same hill where the castle-palace is located. The north wall and part of the south wall, as well as the NW tower and both small towers of the south, are situated on the area that had been one of the castle-palace's quarries, identifying in the bottom section of the towers a stony strata tilting towards the North (Figure 4). The quarrymen probably took advantage of the cracks, joints and planes of stratification that presents this geological formation for extract the rubbles and rough ashlars needed. Because of this, the height and / or the length of the pieces used in the inside zone of the castle present similar dimensions as the thicknesses of the bordering rocky strata (18 to $30 \mathrm{~cm}$; Figures 1 and 5). In addition, at first glance, the whole outside stone masonry (grey), together with its re-joined ones (white), have in their surface a patina of orange tonality that homogenizes the colour of its whole set (Figures 4 and 5).

The Renaissance palace of two floors is formed by a series of dependencies communicated between them and with a central squared courtyard (20 x $20 \mathrm{~m}$ ) (Figure 2). The courtyard is surrounded by two super imposed galleries plants with five arcades on each side. The galleries stand on edging vaults resting towards the interior wall 
muro interior sobre ménsulas finamente talladas en piedra de serpentina (o mármol verde), importadas desde Italia (1-3).

En el patio central, la decoración de sus fachadas mediante arcadas (arcos de medio punto y capiteles) es muy vistosa y cuidada. Aparecen principalmente, motivos florales y geométricos. En las enjutas se representan relieves con los escudos heráldicos de los Mendoza y Fonseca. Las arcadas (arco, capitel, fuste y basa) de la planta baja, así como las bóvedas de sus cuatro lados de galería, están realizados con una variedad de piedra caliza blanda y típica de la zona (1). Es una variedad de grano fino y color anaranjado, fácil de trabajar y labrar. Por el contrario, los escudos que aparecen entre los arcos están tallados en mármol de Carrara (Figura 2), también importado de Italia para este fin decorativo (1-3). Es un mármol calcáreo de textura granoblástica, equigranular y poligonal. En la galería superior, los capiteles, fustes, pedestales, balaustrada, frontón y escudos están tallados también en mármol de Carrara, en el intradós de los arcos hay incrustaciones talladas en piedra verde de serpentina, y el resto de elementos arquitectónicos y decorativos (bóvedas, impostas, cornisa y arcos) están hechos y/o tallados en la piedra caliza local (Figura 2). Todo el conjunto, y sobre todo el mármol de Carrara, presentan una pátina anaranjada, similar a la que aparece en la fábrica exterior.

En los muros de carga interiores, existentes en los dos niveles de galerías y que dan acceso desde el patio a las diversas dependencias del palacio, hay hermosas portadas

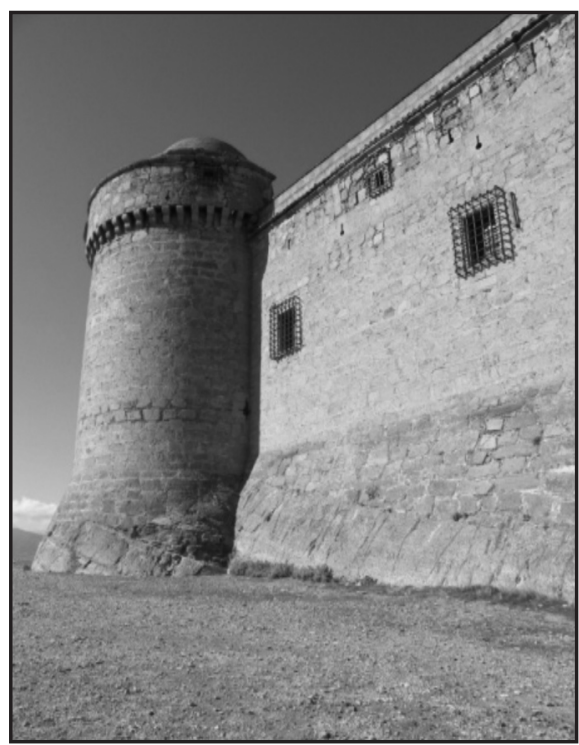

Figura 4. La base de castillo incorpora en muchos de sus muros parte de los afloramientos rocosos-carbonáticos, que fueron utilizados como cantera para su construcción.

Figure 4. The base of castle incorporates in many of its walls part the carbonate rock outcrops that were used as quarry for its construction. on corbels that are carved in serpentine stone (or green marble), imported from Italy (1-3).

In the central courtyard, the decoration of its facade by means of arcades (arch of half a point and capitals) is highly visible and neat. They have principally, floral and geometric motives. The reliefs in the spandrels are the heraldic shields of the Mendoza and Fonseca families. The arcades (arch, capital, shaft and base) of the ground floor, as well as the vaults of its four sides of gallery, are built by a variety of soft limestone typical of the area (1). It is a stone variety of thin grain and orange colour, easy to work and cut. On the contrary, the shields that appear between the arches are carved in Carrara's marble (Figure 2), also imported from Italy for this decorative purpose (1-3). It is a calcareous marble with granoblastic, equigranular and polygonal texture. In the top gallery, the capitals, shafts, pedestals, balustrade, gable and shields are carved also in Carrara's marble. In the inside surface of a vault of the arches there are inlays carved in green stone of serpentine and the rest of architectural and decorative elements (vaults, imposts, cornices and arches) are done and / or carved in the local limestone (Figure 2). The whole set, and especially Carrara marble, shows an orange patina similar to the one that appears in the outside stone masonry.

There are beautiful covers and picture windows, in the walls of inside load, existing in both galleries levels giving both accesses from the courtyard to the diverse

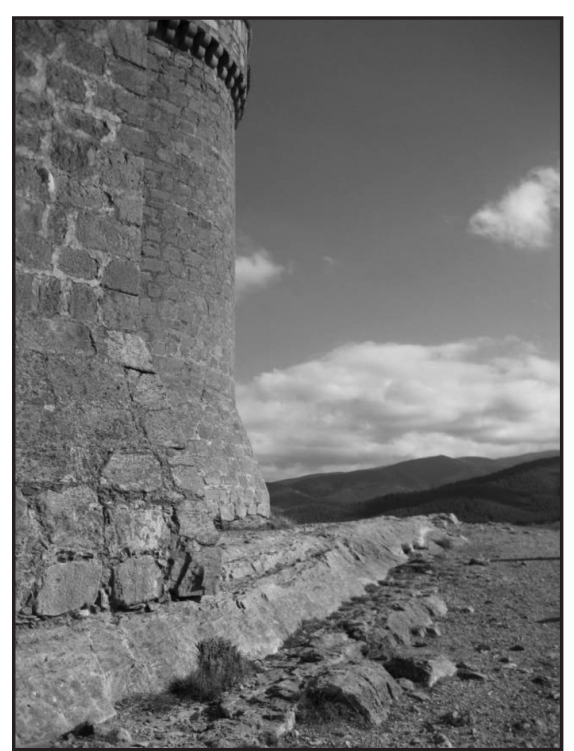

Figura 5. Cerca del castillo son muchos los pequeños bancales extractivos utilizados por canteros de la época para extraer los sillarejos y mampuestos necesarios.

Figure 5. Near the castle there are small extractive plots used by quarrymen of the epoch to extract the necessary rough ashlars and rubbles. 
y ventanales, talladas en una piedra de arenisca local anaranjada y con motivos mitológicos (griego y romanos), bíblicos, frutales, florales y faunísticos. En el centro del ala Oeste, hay una amplia escalera de estilo genovés, que cuenta con tres tramos y está tallada en mármol de Carrara, aunque su estructura de apoyo es una sillería de piedra de arenisca local (Figura 2). Esta escalera ocupa parte del cuerpo rectangular adosado al lado Oeste de la fortaleza y que rompe su simetría $(2,3)$.

En los techos de las principales dependencias hay vigas y hermosos artesonados realizados en madera de conífera (Pinus Sylvestris). En el resto del palacio (muros portantes y de tabiquería, suelos e intradós de bóvedas), la fábrica que aparece es de ladrillo macizo, revestido de mortero de cal (salvo los suelos). También las cúpulas semiesféricas de las torres del castillo están hechas con ladrillo macizo, revestido con mortero de cal.

\section{ESTADO DE CONSERVACIÓN}

Este inmueble presenta algunos defectos en su diseño y posterior mantenimiento, que afectan directamente a su estado de conservación. La zona más deteriorada es la interior y es que al ser un edifico renacentista se cuidó mucho el trazado arquitectónico y la decoración, sacrificando la parte práctica, y es que en lugar de instalar un sistema adecuado de evacuación de las aguas de lluvia, simplemente se colocaron cuatro canalones ocultos de los que partían cuatro gárgolas atravesando la cornisa superior, una en cada esquina del patio central. En intervenciones posteriores, se instalaron, también atravesando la misma cornisa, otros cuatro caños en cada fachada y encima de cada una de las columnas que componen las arcadas (Figura 6). Así pues, se llevan cinco siglos vertiendo directamente las aguas de lluvia, en caída libre, y desde una altura de $11 \mathrm{~m}$, hacia el patio central. En su caída, estas aguas de lluvia junto con la acción del viento, van impactando y lavando por escorrentía, la mayor parte de la zona ornamental y estructural del patio. Las zonas más afectadas son la cornisa y las arcadas de la planta baja (Figuras 2, 6 y 7 ).

Aunque las precipitaciones anuales en la zona no son muy elevadas $(350 \mathrm{~mm})$, si son frecuentes las lluvias fuertes durante los episodios de tormenta. Es por ello, que a lo largo de la trayectoria de caída desde las gárgolas se han detectado un gran número de patologías que afectan principalmente a la piedra caliza local. Existe un fuerte pulido de las superficies ornamentales, talladas en la piedra caliza anaranjada. En las cornisas, impostas y capiteles, donde el agua impacta, hay graves episodios de desplacados, descamados, fisuración, caída de material y arenización, con la consiguiente pérdida de toda la decoración que presentaba (Figuras 6-9). Además, dependences of the palace. There are carved on a local orange sandstone and with mythological (Greek and Romans), Biblical, fruity, floral and animal motives. In the center of the west wing, there is a wide stairs of Genoese style, which possesses three sections and is carved in Carrara's marble, although its support structure are local sandstone ashlars (Figure 2). This stairs occupies part of the rectangular body attached to the west side of the fortress breaking its symmetry $(2,3)$.

In the ceilings of the principal dependences there are beam and beautiful coffered ceilings made in wood of coniferous (Pinus Sylvestris). In the rest of the palace (bearing and partition walls, floors and preassure surface of vaults), the masonry that appears is of massive brick, covered in lime mortar (except the floors). Also the semispherical domes of the towers are made with massive brick, redressed in lime mortar.

\section{CONSERVATION STATE}

This building presents some flaws in its design and later maintenance, which affect directly to its conservation state. The most deteriorated area is the inside one and this is due to the fact that it is a Renaissance building. Its architectural tracing and ornament was certainly cared but the practical part was not taken into consideration. Instead of installing a suitable evacuation system the water, simply four hidden gutters, four gargoyles as water extracting point through the upper cornice were placed, one in every corner of the central courtyard. In later interventions, also crossing the same cornice, other four spouts were installed in every facade and on each of the columns that compose the arcades (Figure 6). So then, for five centuries the rainwater, in free fall, and from a height of $11 \mathrm{~m}$ have been falling into the central courtyard. In its fall, these rainwater together with the action of the wind, are impacting and washing, by run off most of the ornamental and structural zone of the courtyard. The most affected zones are the cornice and the arcades of the ground floor (Figures 2, 6 and 7).

Although the annual rainfalls in the zone are not very high $(350 \mathrm{~mm})$, strong rains are frequent, nevertheless, during the storm episodes. This is the reason why along the path of fall from the gargoyles there have been detected a great number of pathologies (deterioration forms) that affect principally to the local limestone. There is a strong polishing of the ornamental surfaces, which are carved on the orange limestone. In the cornices, imposts and capitals, where the water impact, there are serious episodes of flaking, spalling, cracking, crumbling (sanding) and loss of stone material, with the consequent fall of the ornament decoration they have (Figures. 6-9). In addition, 


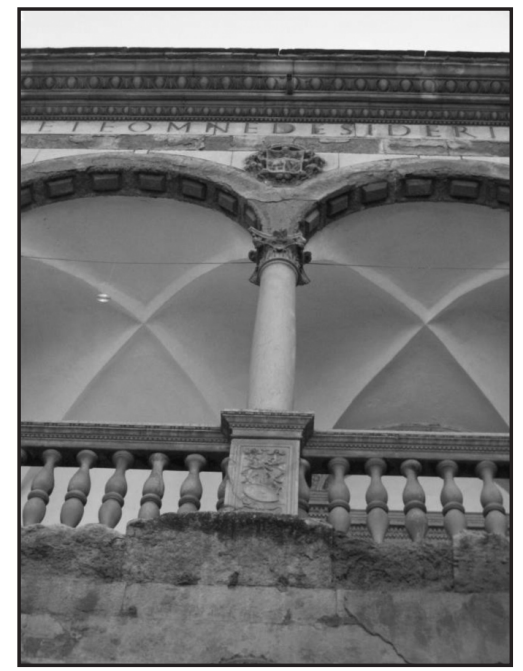

Figura 6. Detalle del estado de conservación de una de las fachadas del patio. Los mayores deterioros se concentran bajo la trayectoria de caída del agua desde el tubo de evacuación. La pérdida de material pétreo afecta principalmente a la piedra caliza local.

Figure 6. Detail of the conservation status of one of the facades of the courtyard. The concentrate further deteriorations under the path of the fall of the rainwater from the outlet pipe. The loss of stone material mainly affects the local limestone.

debido a las salpicaduras de los chorros de agua cuando impactan contra el suelo y revotan, existe una importante pérdida de material pétreo que afecta a las basas y parte baja de los fustes de las arcadas inferiores, y que ha sido reintegrado con diferentes morteros en intervenciones pasadas (Figura 2). Las zonas dañadas carecen de la pátina anaranjada que les caracteriza.

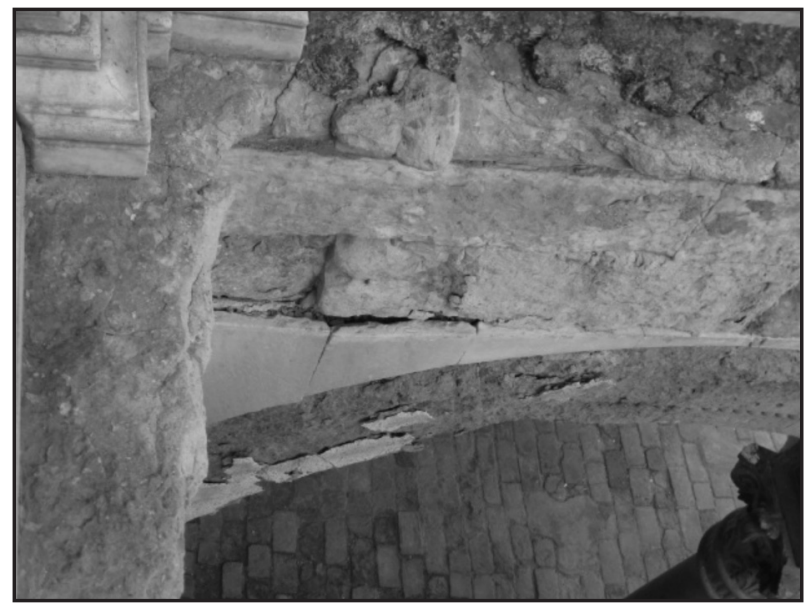

Figura 8. Las placas de mármol corren peligro de caída, al estar en muy mal estado la piedra caliza que la soporta. Figure 8. The marble slabs are in danger of falling, when is in very poor condition the limestone that it supports.

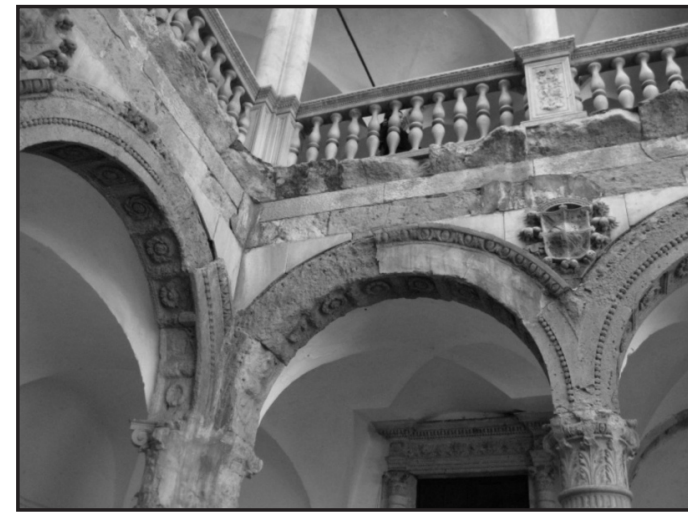

Figura 7. Deterioros en una de las esquinas de la planta baja del patio. La piedra caliza local es la más afectada por la agresión del agua de lluvia y el viento.

Figure 7. Deteriorations forms is one of the corners of the ground floor of the courtyard. The local limestone is most affected by the aggression of the rainwater and the wind.

due to the splashes of the water jets when they impact against the soil and rebound, there exists an important loss of stony material that concerns the bases and lower part of the shafts of the low arcades, and that has been repaired by different mortars in past interventions (Figure 2). The damaged zones lack their peculiar orange patina.

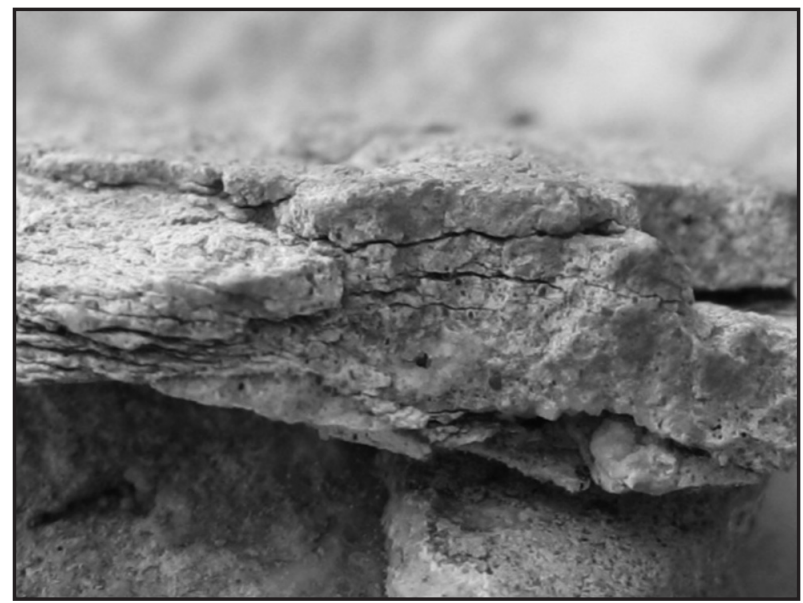

Figura 9. Desplacado de la cornisa que separa la planta alta de la baja. Es visible en su interior la presencia de una fuerte fisuración que delimita múltiples escamas.

Figure 9. Spalling of the cornice that separates the high floor of the ground floor. It is visible in its inside the presence of one strong fissure that delimits multiple flaks. 
Las piezas talladas en mármol de Carrara aparecen en buen estado de conservación, aunque en las zonas de las enjutas de la planta baja, los escudos corren el riesgo de caída, al verse fuertemente debilitada la piedra caliza local sobre la que aparecen adheridas estas placas de mármol (Figura 8). Las piezas esculpidas en piedra de serpentina están protegidas por lo que su conservación es buena.

El suelo de la galería superior, realizado en ladrillo macizo, aparece fuertemente arenizado y con oquedades, debido a la acumulación del agua de lluvia en esta zona. Esto es consecuencia de un defecto de diseño y/o constructivo. Como no hay desagües en esta planta y la base de la balaustra de mármol es maciza y está por encima del nivel del suelo, no hay salida de las aguas de lluvia que voltea el aire hacia el interior, por lo que se acumulan es esta zona, filtrándose hacia la galería inferior, y provocando fuertes humedades en sus bóvedas.

Los muros interiores de ambas galerías, junto con sus bellos ventanales, portadas y arcadas, así como toda la zona de la gran escalera, se encuentran en perfecto estado de conservación, al estar protegidos de los agentes medioambientales más agresivos y carecer de humedades por ascenso capilar. Sólo hay pequeños daños, con pérdida de alguna talla en las bases de varias portadas de la galería inferior, debido a las salpicaduras del chorro de agua de lluvia que cae desde las gárgolas, choca contra el suelo y revota hacia el interior de la galería.

La zona exterior, por el contrario, no tiene ninguna patología grave. Su estado de conservación es muy bueno gracias al tipo de piedra empleado. Sólo en algunas zonas del talud de los muros y torres, la fábrica pétrea aparece sin mortero de rejuntado y sin la pátina anaranjada, debido al lavado por escorrentía, impacto y salpicaduras de las aguas de lluvia combinado con el efecto del viento (Figuras 4 y 5 ).

\section{PARTE EXPERIMENTAL}

Una vez identificados los estilos arquitectónicos empleados en la construcción del castillo-palacio de La Calahorra, y los materiales de construcción que se utilizaron en cada caso, se pasó a recoger algunas muestras representativas de las principales variedades pétreas presentes en la fábrica intacta del exterior del castillo (SE-fragmento sillar exterior) y en la fábrica deteriorada del interior del palacio (SF-desplacados de un fuste, SI-escama de una imposta y SIN-fragmento de un sillar del muro interior, junto a la escalera). El objetivo principal fue caracterizarlas tanto
The pieces carved in Carrara's marble appear in good condition of conservation, although in the zones of the skinny ones of the ground floor, the shields run the risk of falling, as the local limestone on which these plates of marble seem to be adhered is extremely weak (Figure 8). The pieces carved on serpentine stone are protected so its preservation is good.

The floor of the high gallery, realized in massive brick, has become strongly crumbly and with hollows, due to the accumulation of the rainwater in this zone. This is a consequence of a fault of design and / or construction. As there are no drains in this plant and the base of the marble balustrade is massive and is over the level of the floor, there is no exit for the rainwater that turns over the air towards the interior, so they accumulate in this zone, filtering towards the low gallery, and provoking strong dampness in their vaults.

The interior walls of both galleries, together with their beautiful windows, gates and arcades, as well as the whole zone of the great stairs, are in perfect condition of conservation, on having been protected from the most aggressive environmental agents and having lacked dampness for capillary ascent. There are only small damages, with loss of some sculpture in the bases of several gates of the low gallery, due to the splashes of the rain water that falls down from the gargoyles, collide against the ground and rebound towards the inside of the gallery.

The outside zone, on the contrary, does not have any serious decay forms. Its conservation state is very good thanks to the stone variety used. Only in some lower part of the walls and towers, the stone masonry has no grout mortar and orange patina due to leaching by runoff, impact and splashes rainwater combined with the effect of the wind (Figures 4 and 5).

\section{EXPERIMENTAL PART}

Once identified the architectural styles used in the construction of the castle - palace of La Calahorra, and the construction materials that were used in each case, some representative samples of the principal stony varieties intact present in the outside stone masonry of the castle were gathered (SE-exterior ashlar fragment) and in the inside deterioration masonry of the palace (SF-spalling fragment of a shaft, SI-flaking fragment of an impost and SIN-ashlar fragment of the interior wall, next to the stairs). The main objective was to 
desde el punto de vista petrográfico como petrofísico para determinar las causas y mecanismos que condicionaron su diferente respuesta frente a la agresión provocada por los dos agentes principales de deterioro identificados (agua de lluvia y viento).

Las técnicas petrográficas empleadas fueron:

- Microscopía óptica de luz polarizada (MOP), realizada en el departamento de Petrología de la Facultad de Geología (UCM) de Madrid, mediante el uso de un microscopio de polarización Olympus BX51con cámara Olympus DP12. Las láminas delgadas de $30 \mu \mathrm{m}$ de espesor fueron teñidas con AlizarinRed (4) para facilitar la distinción de los componentes calcíticos.

- La difracción de rayos X (DRX) fue realizada en el CAI de Difracción del Instituto de Geociencias (CSIC, UCM) de Madrid y en el Centro Andaluz de Medio Ambiente (CEAMA) de Granada. En Madrid se empleó un equipo Philips PW 1752 con tubo de ánodo de cobre, $2^{\circ}$ y PC-ADP Diffraction Software, y se analizó la fracción polvo de roca total. Analizó la fracción polvo de roca total. En Granada se utilizó un difractómetro de polvo BRUKER D8 ADVANCE, con iguales condiciones de medida.

- La microscopía electrónica de barrido (MEB) se realizó en el Centro Andaluz de Medio Ambiente (CEAMA) de Granada, y se utilizó un microscopio electrónico de barrido Hitachi, S-510 con microanalizador de energía dispersiva de rayos $\mathrm{X}$ Edwin de Röntec (EDX). Se estudiaron fragmentos en modo electrones secundarios (ES), que previamente se habían recubierto con grafito.

La técnica petrofísica utilizada fue la porosimetría por intrusión de mercurio (PIM). Esta técnica permite conocer los valores de densidad real y aparente, así como la porosidad total accesible al mercurio, la forma y tamaño medio de los poros y el tipo de conexión capilar. Igualmente, posibilita la determinación de la distribución porosimétrica de la macroporosidad ( $>5 \mu \mathrm{m}$ de diámetro de poro) y de la microporosidad ( $<5 \mu \mathrm{m}$ de diámetro de poro). La importancia de determinar la macroporosidad y microporosidad se basa fundamentalmente en el hecho de que, a igualdad de condiciones, la microporosidad suele propiciar más la degradación de los materiales.

Este ensayo se realizó en el laboratorio de Petrofísica del Instituto de Geociencias (CSIC, UCM) de Madrid. Se empleó un equipo MICROMERITICS Autopore IV, 9500, con un rango de medida de tamaño de poro comprendida entre 0,001 y $1000 \mu \mathrm{m}$ de diámetro de poro, y la presión ejercida para la intrusión del mercurio abarcaba desde 15 psi hasta 60.000 psi. characterize it from a petrographic and petrophysical point of view to determine the causes and mechanisms that conditioned their different response to aggression caused by two main deterioration agents identified (rainwater and wind).

The petrographic techniques used were:

- Optical microscopy of polarized light (OMP), made in the Petrology Department of the Geology Faculty (UCM) of Madrid, by means of the use of a polarization microscope Olympus BX51 with Olympus DP12

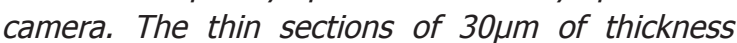
were dyed with Alizarin Red (4) to facilitate the distinction of the carbonate calcium components.

- The diffraction of X-Rays (DXR) was made in the Diffraction CAI of the Geosciences Institute (CSIC, UCM) of Madrid and in the Andalusian Environment Center (ACEAMA) of Granada. In Madrid, there was used an equipment Philips PW 1752 with tube of copper anode was used, $2 \circ$ and a PC-ADP Diffraction Software, and the fraction powder of total rock was analyzed. In Granada, there was used a powder diffractometer BRUKER D8 ADVANCE, with equal conditions of measure was used.

- Scanning electron microscopy (SEM) was carried out in the Andalusian Environment Centre (CEAMA) of Granada, and used a Hitachi, S-510 scanning electron microscope with energy dispersive $X$-ray microanalyzer Edwin Rontec (EDX). Fragments were studied in secondary electrons mode (SE), which had been previously coated with graphite.

The petrophysical technology used was the porosimetry by the mercury intrusion (PIM). This technology allows us to know the values of real and bulk densities, as well as the total accessible porosity to the mercury, the form and average size of the pores and the type of capillary connection. Equally, it makes the determination of the porosimetric distribution of the macroporosity ( $>5 \mu \mathrm{m}$ of pore diameter) and of the microporosity possible ( $<5 \mu$ m pore diameter). The importance of determining the macroporosity and microporosity is based fundamentally in the fact that, for similar conditions, the microporosity usually contribute to a greater degradation of the materials.

This test was carried out in the Petrophysic laboratory of the Geosciences Institute (CSIC, UCM) of Madrid. MICROMERITICS Autopore IV, 9500 equipment was employed, with a range of pore size measure cover between 0,001 and $1000 \mu \mathrm{m}$ of pore diameter, and the pressure exercised for the intrusion of the mercury was included from 15 psi up to 60.000 psi. 


\section{RESULTADOS Y DISCUSIÓN}

\subsection{Caracterización petrográfica}

1. La variedad pétrea presente en la fábrica externa del castillo (SE) es una caliza de textura cristalina y origen diagenético, formada por un mosaico de cristales inequigranulares, mesocristalinos (62-250 $\mu \mathrm{m})$, anhedrales, y de composición calcítica. Es consecuencia de un proceso diagenético de recristalización sufrido por una roca caliza con textura deposicional previa. Localmente, existen cristales aislados y en agregados, de mayor tamaño (hasta $250 \mu \mathrm{m}$ ), subeuhedrales-anhedrales, aspecto marronáceo y composición dolomítica. Su origen se debe a un reemplazamiento diagenético de tipo dolomítico. Además, también ahí grandes fisuras rellenan por cristales de calcita que atraviesan toda esta textura cristalina (Figura 10A). El estudio por DRX confirma la mineralogía general detectada al MOP, calcita como componente principal y dolomita como mineralogía secundaria.

La porosidad existente es mínima y de tipo fisural $(<1 \%)$. Son pequeñas fisuras subparalelas a la superficie (primeros $3 \mathrm{~mm}$ ) y de escaso espesor (Figura 10B), que no afectan al estado general de conservación de la fábrica del edificio. Pueden aparecer vacías o rellenas de partículas rojas y micrométricas. También se han detectado sobre la superficie unos cristales prismáticos de color rojo y tamaño $<60 \mu \mathrm{m}$, cuyo crecimiento se produce de forma perpendicular a la superficie de la caliza (Figura 10B). El estudio al MEB+EDX indica que en ambos casos, son óxidos de hierro (hematites bien cristalizados en superficie), que aparecen recubriendo la superficie de esta sillería de forma natural y de acuerdo a las condiciones medioambientales de la

\section{RESULTS AND DISCUSSION}

\subsection{Petrographic description}

1. The stone variety present in the outside stone masonry of the castle (SW) is a limestone of crystalline texture and diagenetic origin, formed by a crystal mosaic with inequigranular, mesocristalyne (62-250 $\mu \mathrm{m})$, anhedrals forms and sizes, and calcium carbonate composition. It is a consequence of a recrystalization diagenetic process undergone by a limestone rock with a previous depositional texture. Locally, there are single and aggregated crystals (up to $250 \mu \mathrm{m}$ ), subeuhedrals-anhedrals forms, brownish appearance and a dolomitic composition. Its origin is due to a dolomitic diagenetic replacement. In addition, also there are big fissures filled by calcite crystals that cross all this crystalline texture (Figure 10A). The study for XRD confirms the general mineralogy detected to the OMP, the calcite is the principal component and the dolomite is a secondary component.

The existing porosity is minimal and of a fissural type ( $<1 \%)$. They are small fissures subparallel to the surface (first $3 \mathrm{~mm}$ ) and of scanty thickness (Figure 10B), that do not concern the conservation general state of the building. They can turn out to be empty or stuffed of red and micrometric particles. Also on the surface a few prismatic crystals of reddish colour and size $<60 \mu \mathrm{m}$, have been detected, and its growth takes place of a perpendicular form to the limestone surface (Figure 10B). The MEB+EDX study indicates that in both cases, they are iron oxides (hematite well crystallized on surface), that appear covering the surface of this ashlar of natural form and according to the environmental conditions of the

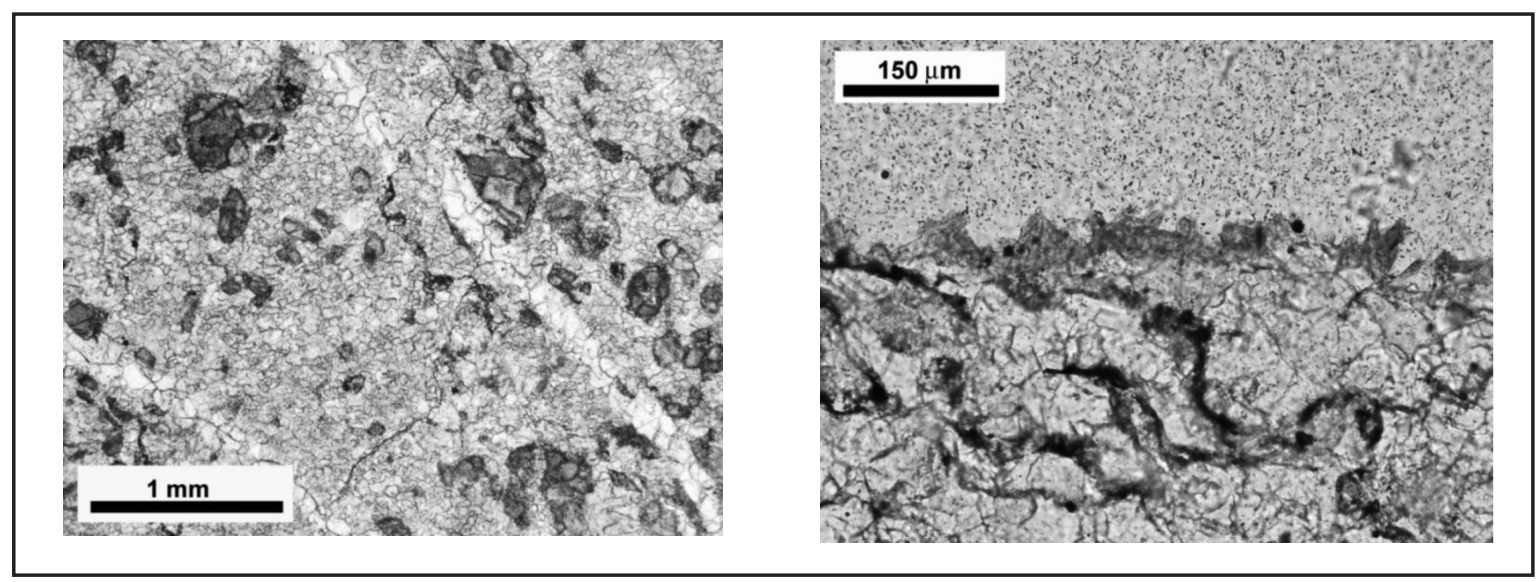

Figura 10. A) Imagen al MOP (nícoles paralelos) de los componentes de la variedad pétrea de la parte externa del castillo. Textura cristalina con cristales claros y pequeños de calcita, y algunos cristales oscuros y grandes de dolomita, cortada por múltiples fracturas rellenas por cristales de cemento calcítico. B) Imagen al MOP (nícoles paralelos) de la capa superficial roja que aparece sobre la caliza.

Son cristales de crecimiento trasversal a la superficie. Las pequeñas fisuras superficiales también aparecen teñidas de rojo.

Figure 10. A) MOP image of the components of stone variety of the outside zone of the castle. Crystalline texture with clear and small crystals of calcite, and some dark and big crystals of dolomite. This texture has been cut by multiple fractures filled by crystals of cement calcite. B) MOP image (one nicoles) of the superficial red layer that appears on the limestone. They are crystals of growth transversal to the surface. The small superficial fissures also turn out to be dyed of red. 
zona. Este elemento químico (hierro) es transportado por el viento desde las minas del Marquesado, en la localidad de Alquife, a $5 \mathrm{~km}$ al Oeste de La Calahorra. La extracción del hierro a cielo abierto en estas minas, data de la época del Imperio Romano y hasta 1996.

Esta variedad pétrea coincide con la litología presente en la mayor parte del cerro donde se asienta el castillo y donde además se han encontrado claros indicios de extracción (pequeños bancales con geometrías lineales y ángulos rectos, -incluso bajo el propio castillo- y huellas de herramientas de cantero - piquetas-) (Figuras 4 y 5).

Desde el punto de vista geológico, son calizas y dolomías cristalinas, de color gris, tableadas, con tamaño de cristal medio y de edad Triásico Medio, pertenecientes al Manto de Santa Bárbara dentro del Complejo Alpujárride de las Cordilleras Béticas (5).

2. La variedad pétrea presente en la fabrica interna del castillo, y concretamente en las arcadas de las fachadas que dan al patio central (SF-desplacado fuste y SI-escama imposta), es una caliza de textura clástica y origen continental. Son facies masivas, micrítica y peletoidales, con un contenido escaso en clastos terrígenos (10-15\%), dispersos en su interior. Estos clastos terrígenos son fragmentos de micaesquistos, cuarcitas, cuarzos monocristalinos y micas. El tamaño medio del grano de los clastos es de 0,125-0,25 mm (arena fina), pero los fragmentos de miscaesquistos son de mayor tamaño (>1 mm). La matriz de textura micrítica y peletoidal, presenta una composición calcítica y procesos de marmorización debidos a las impregnaciones de los óxidos de hierro (Figura 11A). Dentro de la matriz, también se distinguen nódulos densos y masivos de micrita calcítica, con algún clasto terrígeno y películas rojas de óxidos de hierro (Figura 11A). Aparecen en un 5-10\% y sus tamaños oscilan entre $0,5 \mathrm{~mm}$ y $2 \mathrm{~mm}$. Los análisis de DRX, reflejan la presencia de cuarzo, microclina y micas como componentes clásticos, y la presencia de calcita y algo de dolomita y arcillas como componentes de la matriz, de esta variedad pétrea.

Existe además una importante porosidad (10-15\%), de tipo intergranular, canal y vug, parcial o totalmente rellena por cemento esparítico de calcita (DRX). La porosidad intergranular aparece dentro de la matriz micrítica y es la responsable de su textura peletoidal (Figura 11A). También aparece como halos alrededor de los clastos y de los nódulos (Figura 11A). Este tipo de porosidad es debida a procesos de desecación del sedimento. Las porosidades de tipo canal y vug son muy abundantes, aparecen dispersas por la matriz (Figura 11B), tienen tamaños de hasta $2 \mathrm{~mm}$. Esta porosidad es debida a procesos muy intensos de bioturbación por raíces. zone. This chemical element (iron) is transported by the wind from the mines of the Marquesado mines, in Alquife's locality, $5 \mathrm{~km}$ to the West of La Calahorra. The extraction of the iron is opencast in these mines. It dates from the period of the Roman Empire and until 1996.

This stone variety coincides with the lithology present in most of the hill where the castle is settled and where in addition they have found clear indications of extraction (small terrace with linear geometries and right angles - even under the own castle - and footprints of stonecutter's tools - pickaxes -) (Figures 4 and 5).

From the geological point of view, they are crystalline dolostones and limestones of gray colour, pleated, with a medium crystal size and Middle Triassic age, belonging to Santa Barbara Mantle and within the Alpujárride Complex of the Betic mountain range (5).

2. The stone variety present in the inside stone masonry of the castle and concretely in the arcades of the façade that gives to the central courtyard (SF-spalling fragment of a shaft and SI- flaking fragment of an impost), is a limestone of clastic texture and continental origin. They are massive, micritic and peletoidal facies, with few terrigenous clasts (10-15\%) disperse in its interior. These terrigenous clasts, micaschist, and quartzite fragments, monocrystalline quartzes and micas, are formed. The average size of the clasts grain is of 0.125-0.25 mm (fine sand), but the miscaschist fragments are larger. The matrix of micritic and peletoidal texture, presents calcite composition (calcium carbonate) and marmorization processes owed to the impregnations of the iron oxides (Figure 11A). Inside the matrix, there are also distinguished dense and massive nodules of calcitic micrite, with some terrigenous clast and also red layer of iron oxides (Figure 11A). They appear in $5-10 \%$ and their sizes vary between $0.5 \mathrm{~mm}$ and $2 \mathrm{~mm}$. $X R D$ 's analyses reflect the presence of quartz, microcline and micas as clastic components in this stone variety, and the presence of quartz, microcline and dolomite and clays as matrix components.

There is also a significant porosity (10-15\%), of intergranular, channel and vug types, partial or totally filled for calcite esparitic cement (XRD). The intergranular porosity appears within the micritic matrix and is the responsible for its peletoidal texture (Figure 11A). Also appears as haloes about the clasts and nodules (Figure $11 A)$. This porosity type is due to processes of desiccation in the sediment. The porosities of channel and vug types are very abundant, and they appear dispersed within the matrix (Figure 11B), they have sizes up to $2 \mathrm{~mm}$. This porosity is due to intense bioturbation processes in the roots. 
Son facies de calizas con importantes procesos pedogenéticos: bioturbación por raíces, marmorización, nódulos,..., que se corresponden con las calizas palustres y encostramientos del Pleistoceno Superior (Formación Guadix). Se detectan en los barrancos y quebradas del centro y sur de la depresión de Guadix-Baza (5-8), donde se han encontrado algunas canteras. No hay grandes canteras, ni antiguas ni modernas, porque los afloramientos son de escasa potencia.

En la superficie expuesta de las muestras analizadas (SF y SI) se han detectado signos evidentes de deterioro. Hay una fisuración no rellena, paralela y subparalela a la superficie de la piedra (Figura 11B). Puntualmente, se ha detectado un material de relleno formado por partículas oscuras (posible suciedad), rojas (geles de hierro) y cristales de sales. Estas fisuras forman parte de importantes desplacados de $1,8 \mathrm{~cm}$ a $2,4 \mathrm{~cm}$ de espesor que aparecen todas las muestras. Se acentúa su presencia en los primeros $5 \mathrm{~mm}$ superficiales (Figura 11B). También se ha detectado pérdida de material micrítico (procesos de arenización) que afecta de forma desigual a los primeros $3 \mathrm{~mm}$ superficiales. Recubriendo la superficie de estas muestras aparece una película micrométrica de color rojo. Son los geles de hierro que aparecen sobre todas las superficies pétreas, tanto externas como internas. Recubren de forma uniforme y en ocasiones hasta aparecen tapizando las paredes de las fisuras más superficiales.

3. La variedad pétrea presente en la fabrica interna del castillo, y concretamente en los muros interiores de las galerías que dan al patio central (SIN-fragmento sillar muro
They are pelmicritic facies with important pedogenetic processes: bioturbation by roots, marmorization, nodules..., which correspond with the marshy limestones and cruseating of the Late Top Pleistocene (Formation Gaudix). They are detected in the ravines and gullies of the center and south of the of Guadix-Baza depression (5-8), where they have found some quarries. There are no big quarries, either ancient or modern, because the outcrops are underpowered.

In the exposed surface of the analyzed samples (SF and SI) evident decay signs have been detected. There is a non-filled craking, parallel and subparallel to the stone surface (Figure 11B). Promptly, there has been detected a filling material formed by dark particles (possible dirt), red particles (iron gels) and salt crystals. These fissures form part of an important spalling of $(1.8 \mathrm{~cm}$ to $2.4 \mathrm{~cm}$ thickness) that appear in all the samples. Its presence is accentuated in the first $5 \mathrm{~mm}$ surface (Figure 11B). Also, loss of micritic material has been detected (crumbling processes) that concerns to an unequal form the first 3 $\mathrm{mm}$ surface. Covering the surface of these samples a micrometric layer of reddish colour appears. They are the iron gels that appear on all the stone surfaces, both external and internal. Evenly coated and sometimes even appear lining the walls of the most superficial fissures.

3. The stone variety present in the inside stone masonry of the castle and concretely in the interior walls of the galleries facing the central courtyard (SIN-ashlar fragment

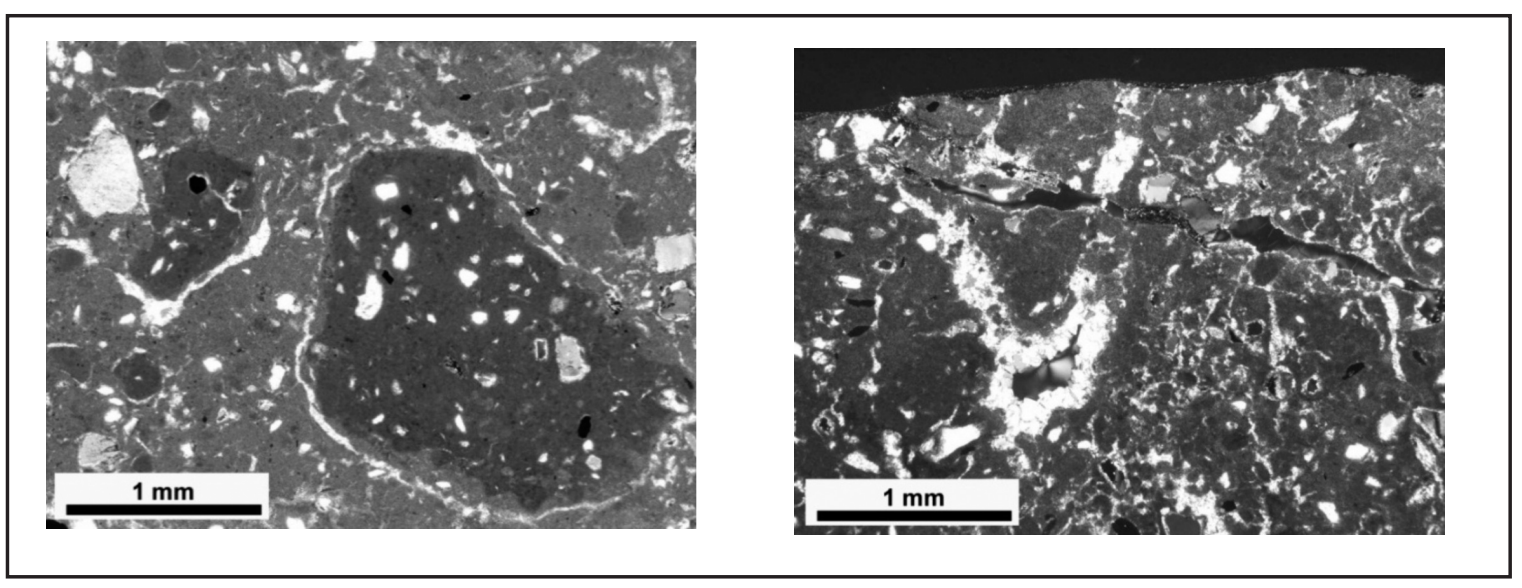

Figura 11. A) Imagen al MOP (nícoles paralelos) de la composición de la variedad pétrea que aparece en impostas, fustes, etc. Los nódulos aparecen rodeados por una película roja de óxidos de hierro y por porosidad fisural rellena con cemento esparítico de calcita. La porosidad es muy importante y se encuentra rellena. B) Imagen al MOP (nícoles cruzados) del deterioro por fisuración sin relleno que aparece en superficie (imposta). La porosidad por bioturbación es alta y está total o parcialmente rellena con cemento de calcita. Figure 11. A) OMP image (one nicol) of the composition of the stone variety that appears in impost, shafts, etc. The nodules turn out to be surrounded by a red film of iron oxide and by fissure porosity stuffed for esparitic cement of calcite. The porosity is very important and turns out to be stuffed. B) OMP image (two nicols) of the deterioration by fissures without landfill that appears in surface (impost). The porosity for bioturbation is high and turns out to be total or partially stuffed for calcite cement. 
junto a escalera), es una arenisca masiva de textura clástica, compuesta por una gran cantidad (50-55\%) de clastos terrígeno de grano fino $(0,125-0,25 \mathrm{~mm})$, y pertenecientes a fragmentos de micaesquistos, cuarcitas, cuarzos y micas (biotitas). Entre los clastos aparece una escasa matriz densa y masiva, con texturas arriñonadas y de color marrón-rojizo. Es una masa de composición carbonatada y textura criptocristalina que contiene óxidos de hierro y minerales de la arcilla (marmorización) (Figura 12). La composición de esta matriz es principalmente dolomítica, pues no se tiñe a rojo con la alizarina. La dolomitización de esta arenisca es un proceso diagenético.

Existe además una importante porosidad (>20\%) de tipo intergranular, canal y vug. La porosidad intergranular aparece como fisuras dentro de la matriz, que están rellenas por cemento esparítico de calcita. Este tipo de porosidad y su relleno posterior es debido a intensos procesos freático-vadosos ocurridos en el sedimento arenoso. Las porosidades de tipo canal y vug, aparecen dispersas por la matriz (10\%), y están vacías. Esta porosidad es debida a la bioturbación del sedimento. No se detecta ningún signo de deterioro en estas muestras.

Son areniscas dolomicríticas, que se corresponden con facies de paleosuelos o encostramientos carbonáticos, formados por la precipitación química de calcita micrítica que posteriormente es reemplazada por dolomita micrítica (procesos diagenéticos), sobre un sedimento detríticoarenoso previo. Desde el punto de vista geológico, son facies de edad Plioceno-Pleistoceno pertenecientes a la Formación de Guadix (5-8). Estas areniscas ligeramente carbonatadas se encuentran por debajo de los niveles carbonatados de la variedad pétrea anterior (SF y SI). Sus afloramientos también aparecen en barrancos y quebradas del centro y sur de la depresión Guadix-Baza, y son más abundantes las canteras antiguas encontradas alrededor del castillo-palacio (a menos de 2 kms de distancia). of the wall, the stairs), is a massive sandstone of clastic texture, composed by a great quantity (50-55\%) of terrigenous clasts of thin grain $(0.125-0.25 \mathrm{~mm})$, and belonging to micaschits, quartzites fragments, quartzes and micas (biotiteas). Between the clasts, appears a scanty dense and massive matrix, with a kidney-shaped texture and reddish brown. It is a mass of carbonated composition and cryptocrystalline texture that contains iron oxides and clay minerals (marmorization) (Figure 12). The composition of this matrix is principally dolomitic, as it is not dyed in red with the alizarine. The dolomitization of this sandstone is a diagenetic process.

There is also an important porosity (> 20\%) of intergranular, channel and vug types. The intergranular porosity appears as fissures within the matrix, which are filled by calcite esparitic cement. This porosity type and backfill is due to intense phreatic - vadoses processes occurring on the sandy sediment. The porosities of channel and vug types, dispersed within the matrix (10\%), and are empty. This porosity is due to the sediment bioturbation. No deterioration signs are detected in these samples.

They are dolomicritic sandstones, which correspond with paleosoils facies or carbonatic crusting, formed by the chemical precipitation of micritic calcite that later is replaced by micritic dolomite (diagenetic processes), on a previous sandy-detritic sediment. From the geological point of view, they are facies of Pliocene - Pleistocene age belonging to the Guadix Formation (5-8). These sandstones lightly carbonated are below the carbonated levels of previous stone variety (SF and SI). Their outcrops also appear in ravines and gullies of center and south of Guadix-Baza depression, and the ancient quarries found around the castle - palace are more abundant (less than $2 \mathrm{~km}$ away).

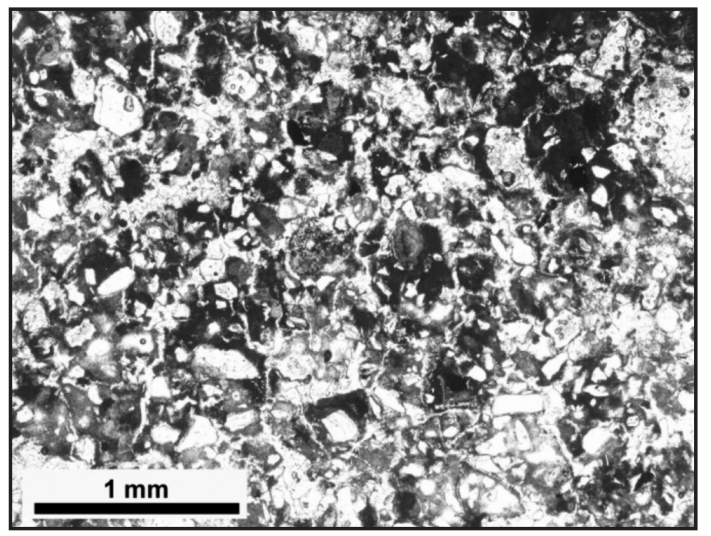

Figura 12. Imagen al MOP (nícoles paralelos) de los componentes de la muestra SIN (sillería interior). El agrietamiento de la matriz es muy importante, aunque está rellena por cemento esparítico-calcítico. Las masas oscuras son una mezcla de óxidos de hierro, arcillas y micrita.

Figure 12. OMP image (parallelized nicol) of the components of the sample SIN (interior ashlar). The cracking of the matrix is very important, though it turns out to be stuffed by esparitic-cement. The dark masses are a mixture of iron oxides, clays and micrite. 


\subsection{Caracterización petrofísica}

En la Tabla 1, se muestra entre otros valores, la densidad real y aparente de los diferentes materiales. Todas las densidades aparecen por encima de $2 \mathrm{~g} / \mathrm{cm}^{3}$, siendo en general densidades altas. Las diferencias entre densidades reales y aparentes son destacables de dos muestras, la del sillarejo exterior (SE) donde la diferencia es mínima y en el sillar interior (SIN) donde esta diferencia es máxima. El primer caso coincide con una porosidad baja $(<1 \%)$, mientras que el segundo caso presenta una mayor porosidad (>24\%).

La muestra SE se desmarca del resto por presentar una superficie específica pequeña $\left(0,246 \mathrm{~m}^{2} / \mathrm{g}\right)$ y un mayor volumen $\left(0,511 \mu \mathrm{m}^{3}\right)$ y tamaño medio de poro $(0,058 \mu \mathrm{m})$, lo que indica que sus poros son grandes y de morfología regular. Por el contrario, la muestra SIN, aparece en el otro extremo con poros pequeños (volumen y tamaño medio de poro, bajos) y muy irregulares (mucha superficie específica). Las conexiones capilares tienen una forma muy similar y aunque en todos los casos la tortuosidad es baja $(<10)$, es la muestra SE (exterior) la que más se acerca a 1 , por lo que sus capilares son los menos sinuosos. Así pues, los escasos poros que hay en la muestra SE son poros grandes, regulares y sus conexiones son de baja sinuosidad. Esto coincidiría con la descripción petrográfica de que la escasa porosidad que tiene es más de tipo fisural.

Las muestras SF y SI, presentan poros grandes y muy pequeños pero de morfología más irregular que en el caso de $\mathrm{SE}$, aunque es más característico los altos niveles de permeabilidad al vapor de mercurio que tiene, lo que refleja una mayor degradación de estas muestras analizadas.

En la Tabla 2 y en la Figura 13, se puede observar la distribución de la porosidad para las diferentes variedades pétreas. En general, son materiales donde la microporosidad ( $<5 \mu \mathrm{m}$ de diámetro de poro) es dominante con más del $60 \%$, siendo la muestra SE la que más se diferencia de las otras tres, pues presenta mucha

\subsection{Petrophysical characterization}

In Table 1, the real and bulk densities of the different materials, among other values, are shown. All the densities appear over $2 \mathrm{~g} / \mathrm{cm}^{3}$, being in general high densities. The differences between real and bulk densities are remarkable in two samples, in the exterior rough ashlar (SE) the difference is minimal and in the interior ashlar (SIN) where this difference is maximum. The first case coincides with a low porosity $(<1 \%)$, whereas the second case presents a major porosity (> 24\%).

The sample SE is dissociated from the rest for presenting a small specific surface $\left(0.246 \mathrm{~m}^{2} / \mathrm{g}\right)$ and higher volume $(0.511 \mu \mathrm{m} 3)$ and medium size of pore $(0.058 \mu \mathrm{m})$, which indicates that their pores are big and of a regular morphology. On the contrary, the sample SIN, appears at the other extreme with small pores (volume and medium size of pore, low) and very irregular (much specific surface). The capillary connections have a similar form and although in all the cases the tortuosity is low $(<10)$, it is the sample SE (exterior) the one that approaches more to 1 , so their capillaries are the least sinuous. Thus, the scanty pores that exist in the sample $S E$, are big and regular pores, and their connections are low sinuosity. This would coincide with the petrographic description that contains low porosity and is fissure type.

The samples SF and SI, present big and very small pores but more irregular morphology that in case of $S E$, although it is more characteristic, the high levels of mercury vapor permeability that has, reflecting further degradation of these analyzed samples.

In Table 2 and in the Figure 13, it is possible to observe the porosity distribution for the different stone varieties. In general, they are material where the microporosity $(<5$ $\mu \mathrm{m}$ of diameter of pore diameter) is dominant with more $60 \%$, being the sample SE the one that more differs from the other three, since it presents many macroporosity

Tabla 1 / Table 1

Características petrofísicas de las diferentes variedades pétreas.

Petrophysical characteristics of the different stone varieties.

\begin{tabular}{|c|c|c|c|c|c|c|c|c|}
\hline $\begin{array}{l}\text { Muestra I } \\
\text { Sample }\end{array}$ & $\begin{array}{c}\text { Densidad } \\
\text { real / Real } \\
\text { density } \\
\left(\mathrm{g} / \mathrm{cm}^{3}\right)\end{array}$ & $\begin{array}{c}\text { Densidad } \\
\text { aparente / } \\
\text { Bulk density } \\
\text { (g/cm3) }\end{array}$ & $\begin{array}{c}\text { Porosidad } \\
\text { I Porosity } \\
\text { (\%) }\end{array}$ & $\begin{array}{l}\text { Superficie } \\
\text { específica / } \\
\text { Specific sur- } \\
\text { face }\left(\mathrm{m}^{2} / \mathrm{g}\right)\end{array}$ & $\begin{array}{c}\text { Volumen de } \\
\text { poro / Pore } \\
\text { volume }\left(\mu \mathrm{m}^{3}\right)\end{array}$ & $\begin{array}{c}\text { Tamaño } \\
\text { medio } \\
\text { de poro I } \\
\text { Average } \\
\text { pore size } \\
(\mu \mathrm{m})\end{array}$ & $\begin{array}{l}\text { Tortuosidad } \\
\text { / Tortuosity }\end{array}$ & $\begin{array}{c}\text { Permeabilidad } \\
\text { / Permeability } \\
\text { (mdarcy) }\end{array}$ \\
\hline SE & 2.74 & 2.71 & 0.98 & 0.246 & 0.511 & 0.058 & 5.44 & 57.98 \\
\hline SIN & 2.70 & 2.03 & 24.57 & 14.477 & 0.066 & 0.033 & 8.24 & 40.35 \\
\hline SF & 2.68 & 2.31 & 13.74 & 3.250 & 0.151 & 0.073 & 9.49 & 100.74 \\
\hline $\mathrm{SI}$ & 2.64 & 2.24 & 14.89 & 9.378 & 0.052 & 0.028 & 7.41 & 94.24 \\
\hline
\end{tabular}


Tabla 2 / Table 2

Distribución porosimétrica de los diferentes materiales.

Porosimetric distribution of different materials.

\begin{tabular}{|c|c|c|c|c|}
\hline & SE & SIN & SF & SI \\
\hline Microporosidad / Macroporosity $(<5 \mu \mathrm{m})$ & $63.9 \%$ & $93.8 \%$ & $78.7 \%$ & $79.5 \%$ \\
\hline Macropososidad / Macroporosity $(>5 \mu \mathrm{m})$ & $36.1 \%$ & $6.2 \%$ & $21.3 \%$ & $20.5 \%$ \\
\hline
\end{tabular}

macroporosidad (>1/3), que coincidiría con las fisuras que presenta. Por el contrario, la muestra SIN, cuenta con una microporosidad dominante con casi el 94\%. Las muestras del fuste (SF) y de la imposta (SI) son muy similares, constituyendo la microporosidad casi las $4 / 5$ partes de la porosidad total. La presencia de altos niveles de microporosidad en las tres muestras del palacio, pueden condicionar y condicionan su grado de deterioro, siendo fácilmente alterables en presencia de los agentes medioambientales más agresivos que actúan en la zona (agua de lluvia y viento).
$(>1 / 3)$, that would coincide with the fissures that it presents. On the contrary, the sample SIN has a dominant microporosity nearly 94\%. The samples of shaft (SF) and impost (SI) are very similar, constituting the microporosity almost 4/5 parts of the total porosity. The presence of high levels of microporosity in three samples of the palace can determine and condition its deterioration degree, being easily alterable in presence of more aggressive environmental agents which acts in the zone (rainwater and wind).
\% Incremento de volumen de Intrusión - Tamaño de poro / Increased intrusion volume (\%) /pore size ( $\mu m)$

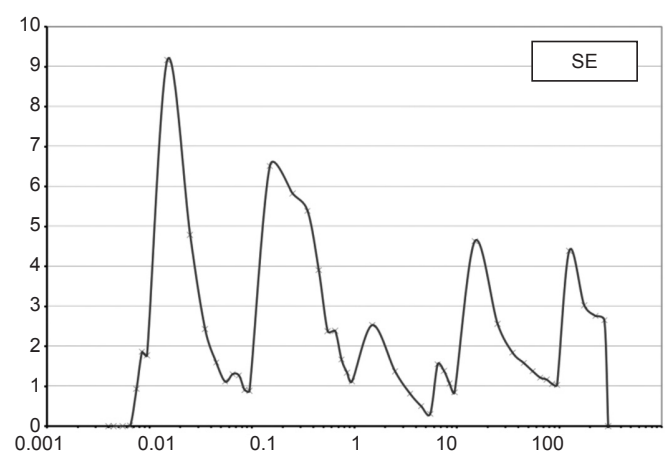

\% Incremento de volumen de Intrusión - Tamaño de poro / Increased intrusion volume (\%) /pore size $(\mu \mathrm{m})$

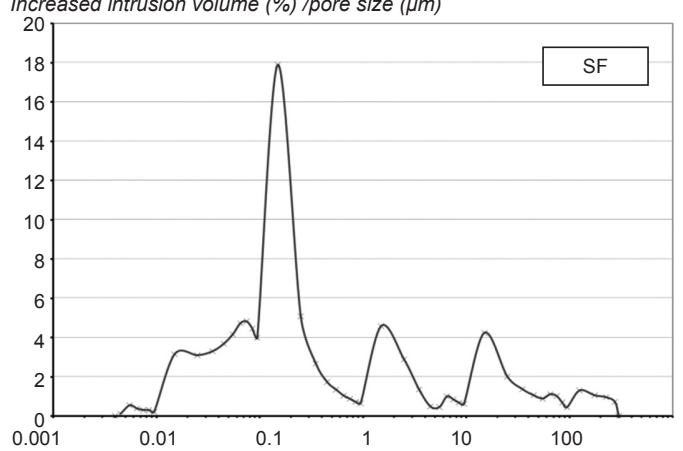

$\%$ Incremento de volumen de Intrusión - Tamaño de poro / Increased intrusion volume (\%) /pore size $(\mu \mathrm{m})$

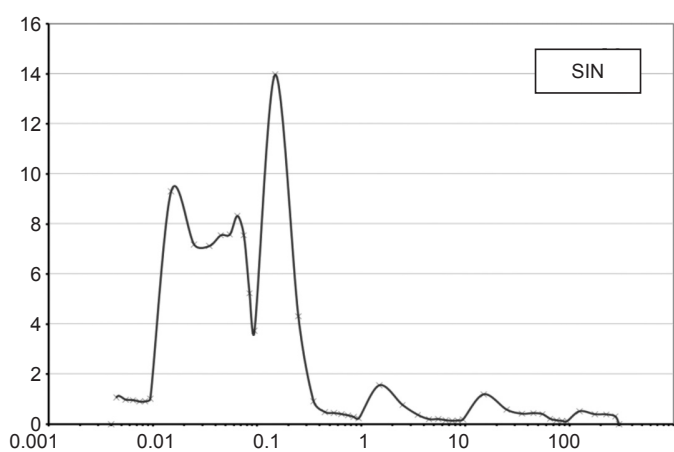

$\%$ Incremento de volumen de Intrusión - Tamaño de poro / Increased intrusion volume (\%) /pore size ( $\mu \mathrm{m})$

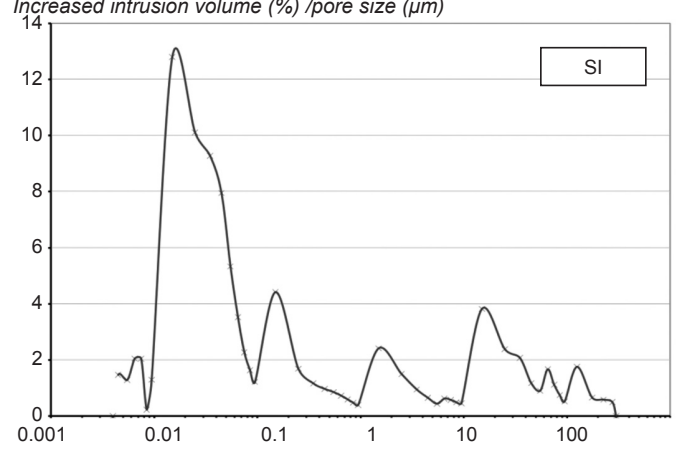

Figura 13. Distribución porosimétrica en las principales variedades pétreas presentes en el castillo-palacio de La Calahorra. Figure 13. Porosimetric distribution in the main stone varieties, present in La Calahorra castle-palace. 


\section{CONCLUSIONES}

El castillo-palacio de La Calahorra consta de una edificación militar en el exterior y de un palacio renacentista en su interior. La parte exterior se construyó utilizando la caliza cristalina que aparece en el cerro donde de levantó. Es una variedad pétrea dura, poco porosa y resistente, por lo que su estado de conservación actual es bastante bueno. Por el contrario, la parte interior se edificó utilizando dos variedades pétreas muy similares. Son materiales detríticocarbonatados, blandos y poco resistentes por su elevada porosidad (principalmente microporosidad), pero eran fáciles de trabajar y tallar. Esto ha provocado que la acción de los agentes medioambientales más activos en la zona (agua de lluvia y viento), junto con el defecto constructivo de no contar con un sistema de evacuación de aguas de lluvia adecuado, ha afectado gravemente a la conservación y estabilidad de las fachadas del patio central. El mármol de Carrara utilizado en la decoración de estas fachadas se encuentra en buen estado de conservación pero su estabilidad peligra al estar colocadas estas piezas sobre la caliza deteriorada que configura la estructura de estas fachadas.

Además, es característico la presencia de una hermosa pátina anaranjada que homogeneiza el color de todo el edificio y que ha sido transportado por los vientos del Oeste desde las vecinas minas de Alquife, durante los cinco siglos de su coexistencia. Las zonas afectadas por el deterioro carecen de esta pátina al haber sido eliminada por la acción de los agentes de deterioro.

\section{AGRADECIMIENTOS}

Este trabajo ha sido cofinanciado por la Comunidad de Madrid a través del programa Geomateriales (S2009/MAT1629) y por el Ministerio de Economía y Competitividad (MINECO) a través del programa Consolider-Ingenio 2007 (CSD2007-0058). Además forma parte de las actividades del grupo de investigación de la UCM "Alteración y Conservación de los Materiales Pétreos del Patrimonio" (ref. 921349).

\section{CONCLUSIONS}

La Calahorra is a military building in the outside and a Renaissance palace in its inside. The outside zone was constructed using crystalline limestone that appears in the hill where it was raised. It is a hard, slightly porous and resistant stone variety; its conservation state is very good. On the contrary, the inside zone was built using two stone varieties very similar. They are detrital carbonated materials, soft and low resistence due to its high porosity (microporosity mainly), but they were easy to work and carving. This has provoked that the action of the most active environmental agents in the zone (rainwater and wind), together with the constructive fault of not possessing a proper system of rainwater evacuation adapted, has affected seriously to the conservation and stability of the façades of the central courtyard. Carrara marble used in the decoration of these façades is in good conservation state but its stability is in danger as these pieces are placed on the deteriorated limestone that forms the structure of these façades.

In addition, the castle-palace is typical for the presence of a beautiful orange patina that homogenizes the colour of whole building and that has been transported by the winds of the West from neighboring Alquife mines, during five centuries of its coexistence. The zones affected by the deterioration lack this patina having been eliminated by the action of the deterioration agents.

\section{ACKNOWLEDGEMENTS}

This project forms part of the Geomateriales research programme (S2009/MAT-1629), funded by the Autonomous Community of Madrid, and the Ministry of Education and Finance (MINECO) Consolider-Ingenio programme (CSD20070058). It is one of the research projects implemented by the UCM (Complutense University of Madrid) group 'Alteration and ConservationofStoneMaterialsintheBuiltHeritage'(no.921349).

\section{REFERENCIAS / REFERENCES}

(1) Nieto-Alcaide, V.M.; Checa-Cremades, F.: Arquitectura del Renacimiento en España 1488-1599. Madrid (1989).

(2) Henares-Cuéllar, I.; López Guzmán, R.: El Castillo-Palacio de la Calahorra. Alzada, COAAT Granada, vol. 72 (2004), pp. 52-68.

(3) Guardia-Olmedo, J.J.; Varas-Muriel, M.J.: Studied the Natural and Artificial Materials used in the Construction of the Calahorra, Granada, Spain. I Congreso Internacional de Investigación en Edificación. Libro de Abstracts, p. 71, Madrid (2009).

(4) Lindholm, R.C.; Finkelman, R.B.: "Calcite staining: semiquantitative determination of ferrous iron", Journal of Sedimentary Petrology, vol. 42 (1972), pp. 239-242.

(5) Magna no 1011 (Guadix): Mapa Geológico de España 1:50.000. 1a Edición, 2a Serie. IGME. Madrid (1980).

(6) Vera, J.A.: "Estudio estratigráfico de la depresión de Guadix-Baza". Bol. Geol. Min., vol. 81 (1970), pp. 429-462.

(7) Freytet, P.; Plaziat J.: Continental carbonate sedimentation and pedogenesis. Contributions to sedimentology, 11. Schweizerbart-Verlagsbuch (1982), $216 \mathrm{pp}$.

(8) Arribas, M.E.; Fernández, J.; García-Aguilar J.M.: "Análisis sedimentológico de los materiales lacustres (Formación de Gorafe-Huelago) del sector central de la depresión de Guadix". Estudios Geol., vol. 44 (1988), pp. 61-73. 